\title{
QUALITY CONTROL OF MEAT FUNCTIONAL CUTLETS
}

\author{
M. Paska, O. Masliichuk
}

Stepan Gzhytskyi National University of Veterinary Medicine and Biotechnologies Lviv

\begin{tabular}{l} 
Key words: \\
Minced meat \\
Lupin flour \\
Inula \\
Minced semi-finished \\
products \\
Meat functional cutlets \\
\hline
\end{tabular}

Article history:

Received 05.09.2018

Received in revised form 21.09.2018

Accepted 04.10.2018

Corresponding author:

M. Paska

E-mail:

npnuht@ukr.net

\begin{abstract}
The nutrition of all population groups of Ukraine is an important agent that to a large extend determine the health of the nation. While solving the problem with the albumen shortage the main part as a raw material plays legumes. Having conducted series of studies we recommend to use lupin flour and inula in the technology of meat cut into semi-finished products for solving the problem with albumen shortage and complete rational nutrition. Food products must be high qualitive, correspond to meet state standarts and technical conditions.
\end{abstract}

The aim of the work is the analysis of the sensory indicators of meat functional cutlets and the toxicity of cutlets with $10 \%$ lupin flour and inula.

As for the control the recipe in accordance with GOST R-52675-2006 has been chosen. Sensority indicators of the meat functional cutlets are rated by a 5 -point scale. The results are processed by the mathematical statistics method. According to "Methods for determining toxicity on laboratory animals" the white laboratory mice were fed during 10 days.

The tasting of the meat functional cutlets was held, the sensority characteristic were given, and the quality was determined in conditions in vivo.

The best sample was determined (№ 2 contains $10 \%$ of lupid flour and $0,05 \%$ of inula). While feeding mice with cutlets with $10 \%$ content of lupin flour and $0,05 \%$ of inula, it was established that during pathoanatomical dissection, macroscopic changes in the organs and tissues were not found. The weight of organs $(p<0,05)$ was in normal range and it confirms that this product can be included to the diet of humans.

It was found that meat functional cutlets are qualitative and can be included in the humans diet for solving the problems of protein deficiency. A patent was produced for this product and series of studies are continued for implementation in production.

DOI: $10.24263 / 2225-2924-2018-24-5-17$ 


\section{КОНТРОЛЬ ЯКОСТІ М'ЯСНИХ ФУНКЦІОНАЛЬНИХ КОТЛЕТ}

\section{М.3. Паска, О.Б. Маслійчук}

Львівський національний університет ветеринарної медицини та біотехнологій імені С.3. Гжицьького

Харчування всіх груп населення України є важливим фактором, що значною мірою визначає здоров'я начії. При вирішенні проблеми дефіциту білка велику роль відіграють зернобобові культури як сировини для його виробництва. Тож рекомендовано використовувати люпинове боромно та дивосил y технології м'ясних посічених напівфабрикатів для вирішення проблеми дефіциту білка та повночінного рачіонального харчування. Харчова продукиія повинна бути якісною та відповідати вимогам державних стандартів $i$ технічним умовам.

Метою дослідження є аналіз сенсорних показників м'ясних функиіональних котлет та контроль токсичності котлет з 10-відсотковим вмістом люпинового борошна та дивосилу. Для досягнення поставленої мети були поставлені такі завдання: розроблення рецептури та технологічної схеми виробництва МФК; оцінка сенсорних показників якості МФК; визначення токсичності МФК з 10-відсотковим вмістом люпинового борошна та дивосилу за умов згодовуванням білим мишам як основного корму протягом 10 днів; аналіз при патологоанатомічному розтині мишей стану внутрішніх органів та аналіз гематологічних досліджень крові.

За контроль було обрано рещептуру згідно з ГОСТ Р 52675-2006. Сенсорні показники м'ясних функиіональних котлет оиінені за 5-бальною шкалою. Результати оброблені методом математичної статистики. Білих лабораторних мишей годували протягом 10 днів за методикою визначення токсичності на лабораторних тваринах.

Визначено найкращий зразок (№ 2, щุо містить $10 \%$ люпинового борошна та 0,05\% дивосилу). Після згодовування мишам котлет з 10-відсотковим вмістом люпинового борошна та 0,05\% дивосилу при патологоанатомічному розтині макроскопічних змін в органах і тканинах не виявлено. Маса органів $(p<0,05)$ знаходиться в межах норми та підтверджує, що продукт можна включати в раціон харчування людей.

Встановлено, що м'ясні функціональні котлети відповідають якості та можуть використовувати у харчуванні людей при вирішенні проблеми білкового дефіциту. На продукиію виготовлено патент. Продовжуються дослідження для впровадження у виробниитво.

Ключові слова: м'ясний фари, люпинове борошно, дивосил, посічені напівфабрикати, м'ясні функиіональні котлети.

Постановка проблеми. В Україні спостерігається проблема білкового дефіциту, тому пошук нових джерел повноцінного білка і впровадження нових видів продукції з високою харчовою цінністю $є$ надзвичайно важли- 
вим. М'ясні посічені напівфабрикати становлять велику частку в харчовому раціоні населення. Тож виробництво м'ясних функціональних котлет, що поєднують у рецептурі м'ясну сировину та білки рослинного походження, набуває особливої актуальності. Серед значної кількості сировини рослинного походження, що містить білок, особливе місце належить люпину. На Всесвітньому конгресі у США з проблем використання рослинних білків для харчових і кормових цілей ця рослина характеризувалася як важливий резерв білкових речовин високої якості [1]. У цілому використання насіння люпину в харчовій промисловості обмежене через наявність у ньому гірких і отруйних алкалоїдів. Проте на сьогодні вирощений білий люпин сортів «Харчовий», «Синій парус», «Олежка», «Володя», «Володимир». Головна особливість цих сортів полягає в тому, що білки не потребують термічної обробки, тому що не містять інгібіторів протеолітичних ферментів: трипсину та хімотрипсину, фітогемоглютенінів, нейротоксинів та альфа-галактоз [1;2].

На відміну від інших бобових культур, у насінні білого харчового люпину міститься $10 \ldots 12 \%$ жирів, комплекс вітамінів, макро- і мікроелементи та інші біологічно активні речовини. Вони захищають організм від радіонуклідів i важких металів, а також прискорюють процес їхнього видалення. Харчові волокна цих сортів люпину, які містяться в переважній більшості в оболонці (80...88\%), решта - в ядрі насіння (15...18\%), є досить добрими ентеросорбентами радіонуклідів, стронцію, цезію та інших важких металів [2]. Ефект ентеросорбції вони виявляють також стосовно холестерину, жовчі та інших продуктів обміну. Тож зерно харчових сортів білого люпину доцільно використовувати у виробництві високобілкових продуктів дитячого, дієтичного та лікувально-профілактичного призначення.

Харчова продукція повинна відповідати вимогам якості державних стандартів, технічним умовам за сенсорними показниками та показниками безпечності.

Аналіз останніх досліджень і публікацій. У сучасних умовах, відповідно до вимог міжнародної системи самоконтролю (НАССР), особливе значення надається проблемі контролю якості і безпеки харчових продуктів [3].

Відомі розробки виготовлення м'ясних посічених напівфабрикатів, що включають внесення у фарш м'ясних екстрактів і порошків, субпродуктів або продуктів їх переробки, гідратованого соєвого білка, рослинних і біологічно активних добавок, харчових волокон, олії тощо. До недоліків цих розробок відносять складність рецептури приготування, недоступність інгредієнтів, низьку харчову та біологічну цінність продукції. Зокрема, у [4-6] описується введення в м'ясні січені напівфабрикати білкових компонентів, в основному соєвих концентратів, висівок, сироваток тощо.

Питанню контролю м'ясної продукції на вміст важких металів приділяють особливу увагу. Концентрації елементів алюмінію, миш'яку, кадмію, хрому, кобальту, міді, свинцю, ртуті, нікелю, селену і цинку потрапляють у м'ясо при забруднені повітря і рослинності [7].

У Сербії та Іспанії проводять дослідження продуктів харчування на токсичність, виявляючи вміст $\mathrm{Pb}, \mathrm{Cd}, \mathrm{Hg}$, Аs. 3'ясовано, що наявність цих елементів 
у продукції призводить до споживання дорослою людиною 72,30 мкг у день, As та Cd - 21,89 мкг та 11,51 мкг [8].

Ми скористалися аналізом сенсорних показників якості сировини та провели дослідження на білих мишах [9]. Визначення токсичності на живих організмах $\epsilon$ найефективнішим методом перевірки нетоксичності та впровадження сировини у виробництво.

Мета дослідження: аналіз сенсорних показників МФК і контроль токсичності м'ясних функціональних котлет $з$ 10-відсотковим вмістом люпинового борошна та дивосилу.

Матеріали і методи досліджень. За контроль було обрано рецептуру згідно з ГОСТ Р 52675-2006. Сенсорні показники МФК оцінені за 5-бальною шкалою. Дослідження проводилися на кафедрі технології м'яса, м'ясних та олійно-жирових виробів Львівського національного університету ветеринарної медицини та біотехнологій ім. С.3. Гжицького. Результати оброблені методом математичної статистики.

Методи визначення токсичності готових $10 \%$ котлет за умов згодовуванням білим мишам як основного корму протягом 10 днів гематологічні дослідження наведено в [10].

Викладення основних результатів дослідження. Рецептури м'ясних функціональних котлет наведені в табл. 1. За контроль було обрано рецептуру згідно з ГОСТ Р 52675-2006.

Таблиця 1. Рецептури м'ясних функціональних котлет

\begin{tabular}{|c|c|c|c|c|c|c|}
\hline \multirow{2}{*}{$\begin{array}{c}\text { Найменування } \\
\text { сировини }\end{array}$} & \multicolumn{5}{|c|}{ Котлети } \\
\cline { 2 - 7 } & \multicolumn{2}{|c|}{$5 \%$} & \multicolumn{2}{c|}{$\begin{array}{c}\text { Котлети } \\
10 \%\end{array}$} & \multicolumn{2}{c|}{$\begin{array}{c}\text { Котлети } \\
15 \%\end{array}$} \\
\cline { 2 - 8 } & Брутто & Нетто & Брутто & Нетто & Брутто & Нетто \\
\hline $\begin{array}{c}\text { Яловичина } \\
\text { (котлетне м'ясо) }\end{array}$ & 68,4 & 51,3 & 64,8 & 48,6 & 61,2 & 45,9 \\
\hline Борошно люпину & 2,7 & 2,7 & 5,4 & 5,4 & 8,1 & 8,1 \\
\hline Жир-сирець & 5,0 & 5,0 & 5,0 & 5,0 & 5,0 & 5,0 \\
\hline Хліб пшеничний & 13,0 & 13,0 & 13,0 & 13,0 & 13,0 & 13,0 \\
\hline Сухарі панірувальні & 2,0 & 2,0 & 2,0 & 2,0 & 2,0 & 2,0 \\
\hline Цибуля ріпчаста & 3,6 & 3,0 & 3,6 & 3,0 & 3,6 & 3,0 \\
\hline $\begin{array}{c}\text { Перець } \\
\text { чорний мелений }\end{array}$ & 0,05 & 0,05 & 0,05 & 0,05 & 0,05 & 0,05 \\
\hline Порошок дивосилу & 0,05 & 0,05 & 0,05 & 0,05 & 0,05 & 0,05 \\
\hline Сіль харчова & 1,2 & 1,2 & 1,2 & 1,2 & 1,2 & 1,2 \\
\hline Вода & 21,7 & 21,7 & 21,7 & 21,7 & 21,7 & 21,7 \\
\hline $\begin{array}{c}\text { Маса } \\
\text { напівфабрикату }\end{array}$ & - & 100 & - & 100 & - & 100 \\
\hline Жир рослинний & 7 & 7 & 7 & 7 & 7 & 7 \\
\hline $\begin{array}{c}\text { Вихід } \\
\text { готового продукту }\end{array}$ & - & 75 & - & 75 & - & 75 \\
\hline
\end{tabular}

Технологічну схему виробництва м'ясних функціональних котлет наведено на рис. 1. 


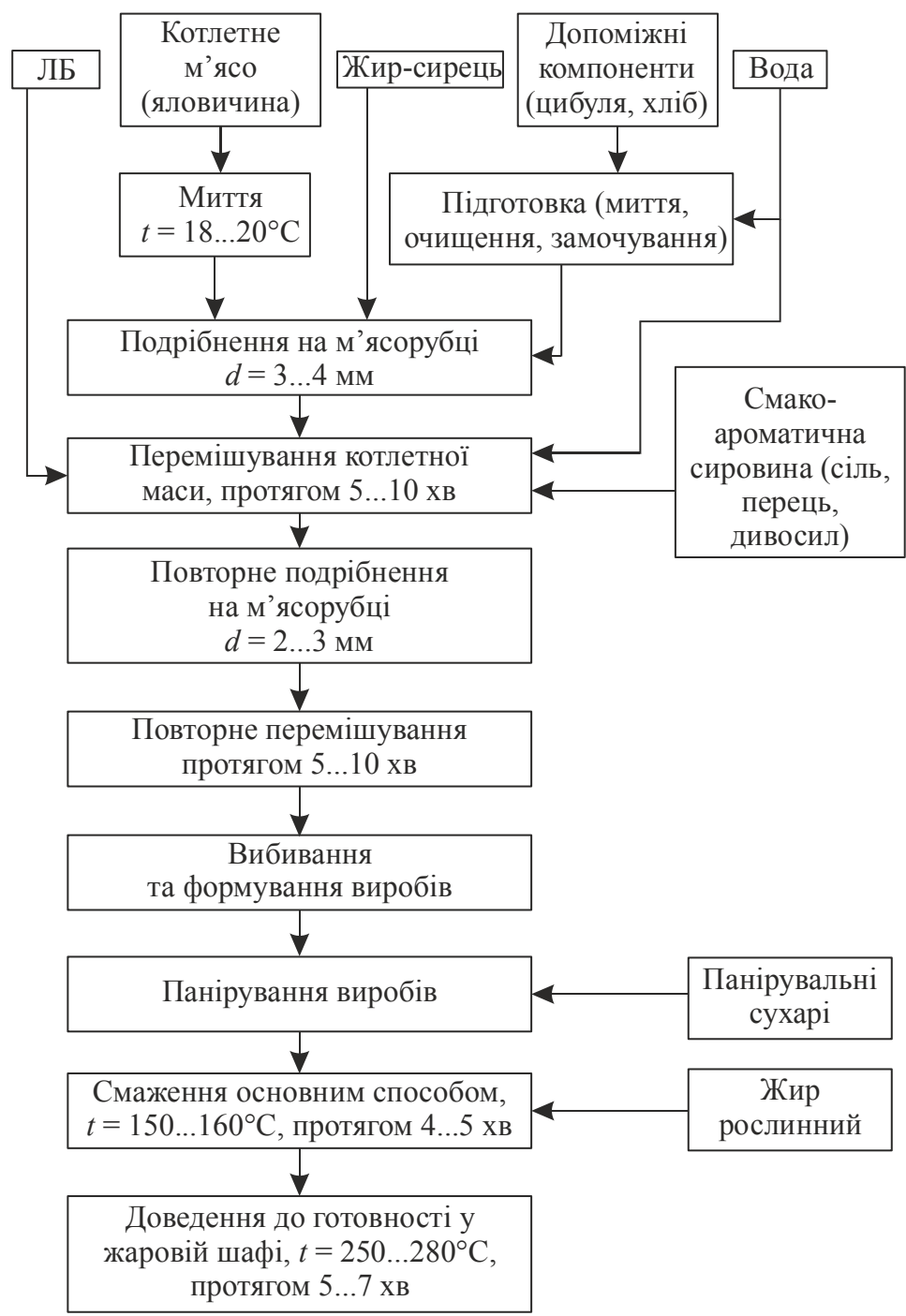

Рис. 1. Технологічна схема виробництва МФК

Характеристику контрольних і дослідних зразків м'ясних функціональних котлет наведено в табл. 2.

\section{Таблиця 2. Шкала органолептичних характеристик МФК}

\begin{tabular}{|c|c|c|c|c|}
\hline \multirow{2}{*}{ Показник } & \multicolumn{4}{|c|}{ Бальна оцінка } \\
\hline & Відмінно & Добре & Задовільно & Незадовільно \\
\hline 1 & 2 & 3 & 4 & 5 \\
\hline $\begin{array}{c}\text { Зовнішній } \\
\text { вигляд }\end{array}$ & $\begin{array}{c}\text { Форма оваль- } \\
\text { но-приплюсну- } \\
\text { та, панірува- } \\
\text { ння нанесено } \\
\text { рівномірним } \\
\text { шаром }\end{array}$ & $\begin{array}{c}\text { Форма овально- } \\
\text { приплюснута, } \\
\text { панірування } \\
\text { нанесено } \\
\text { нерівномірним } \\
\text { шаром }\end{array}$ & $\begin{array}{c}\text { Форма злегка поруше- } \\
\text { на, на поверхні наявні } \\
\text { незначні вм’ятини та } \\
\text { тріщини, панірування } \\
\text { нанесено нерівно- } \\
\text { мірним шаром }\end{array}$ & $\begin{array}{c}\text { Форма не відповідає } \\
\text { вимогам, краї «рвані», } \\
\text { на поверхні наявні } \\
\text { вм’ятини та тріщини, } \\
\text { панірування нанесено } \\
\text { нерівномірним шаром }\end{array}$ \\
\hline
\end{tabular}




\begin{tabular}{|c|c|c|c|c|}
\hline \multicolumn{5}{|r|}{ Продовження табл. 2} \\
\hline 1 & 2 & 3 & 4 & 5 \\
\hline $\begin{array}{l}\text { Колір } \\
\text { поверхні }\end{array}$ & $\begin{array}{l}\text { Золотаво- } \\
\text { коричневий, } \\
\text { рівномірний, } \\
\text { на розрізі } \\
\text { однорідний, } \\
\text { сірий }\end{array}$ & $\begin{array}{c}\text { Золотаво- } \\
\text { коричневий, } \\
\text { місцями } \\
\text { неоднорідний, } \\
\text { на розрізі } \\
\text { однорідний, } \\
\text { сірий }\end{array}$ & $\begin{array}{c}\text { Неоднорідний із } \\
\text { коричневими } \\
\text { ділянками, на розрізі } \\
\text { однорідний, сірий }\end{array}$ & \begin{tabular}{|c} 
Неоднорідний із \\
підгорілими ділянками, \\
на розрізі \\
нерівномірний, \\
червоно-сірий
\end{tabular} \\
\hline Запах & $\begin{array}{c}\text { Відповідний } \\
\text { сировинним } \\
\text { компонентам }\end{array}$ & $\begin{array}{c}\text { Відповідний } \\
\text { сировинним } \\
\text { компонентам }\end{array}$ & $\begin{array}{c}\text { Відповідний } \\
\text { сировинним } \\
\text { компонентам, із } \\
\text { легким стороннім } \\
\text { запахом } \\
\end{array}$ & $\begin{array}{l}\text { Невідповідний } \\
\text { сировинним } \\
\text { компонентам }\end{array}$ \\
\hline $\begin{array}{c}\text { Консис- } \\
\text { тенція }\end{array}$ & $\begin{array}{l}\text { М'яка, ніжна, } \\
\text { в міру пружна }\end{array}$ & М'яка, пружна & \begin{tabular}{|c|} 
Надміру пружна або \\
надміру м'яка
\end{tabular} & $\begin{array}{c}\text { Дуже пружна або } \\
\text { мазеподібна }\end{array}$ \\
\hline Смак & $\begin{array}{c}\text { Відповідний } \\
\text { сировинним } \\
\text { компонентам }\end{array}$ & $\begin{array}{c}\text { Відповідний } \\
\text { сировинним } \\
\text { компонентам }\end{array}$ & $\begin{array}{c}\text { Відповідний } \\
\text { сировинним } \\
\text { компонентам, із } \\
\text { легким стороннім } \\
\text { смаком } \\
\end{array}$ & $\begin{array}{l}\text { Невідповідний } \\
\text { сировинним } \\
\text { компонентам }\end{array}$ \\
\hline $\begin{array}{l}\text { Сокови- } \\
\text { тість }\end{array}$ & Соковиті & Соковиті & В міру соковиті & Сухі, розсипчасті \\
\hline
\end{tabular}

Для органолептичної оцінки були обрані дослідні зразки яловичих котлет 3 додаванням люпинового борошна та дивосилу. Результати статистичної обробки результатів наведено у табл. 3, де відображено органолептичний аналіз дослідного продукту і його оцінка за категоріями.

\section{Таблиця 3. Органолептичні показники м'ясних функціональних котлет}

\begin{tabular}{|c|c|c|c|c|c|c|c|c|}
\hline \multirow{2}{*}{$\begin{array}{c}\text { № } \\
\text { п/п }\end{array}$} & $\begin{array}{c}\text { Назва } \\
\text { продукту }\end{array}$ & $\begin{array}{c}\text { Зовнішній } \\
\text { вигляд }\end{array}$ & Колір & Запах & $\begin{array}{c}\text { Консис- } \\
\text { тенція }\end{array}$ & Смак & $\begin{array}{c}\text { Сокови- } \\
\text { тість }\end{array}$ & $\begin{array}{c}\text { Загальна } \\
\text { оцінка } \\
\text { в балах }\end{array}$ \\
\hline 1 & Контроль & 5,0 & 5,0 & 5,0 & 4,5 & 5,0 & 4,5 & 4,83 \\
\hline 2 & Зразок № 1 & 4,8 & 5,0 & 5,0 & 4,5 & 5,0 & 4,5 & 4,80 \\
\hline 3 & Зразок № 2 & 4,8 & 5,0 & 5,0 & 4,8 & 5,0 & 5,0 & 4,93 \\
\hline 4 & Зразок № 3 & 4,0 & 4,6 & 4,6 & 4,0 & 4,0 & 4,0 & 4,2 \\
\hline
\end{tabular}

Встановлено, що отриманий продукт за рецептурою № 2 на смак, запах, колір, консистенцію відповідає контролю та за соковитістю найкращий і має високу оцінку.

На рис. 2 зображена органолептична оцінка МФК. 3 діаграми видно, що найкращі сенсорні характеристики має варіант № 2.

Встановлено, що найкращими сенсорним характеристиками володіє зразок № 2, що підтверджує доцільність впровадження даного виду у промислових масштабах. На рецептуру розроблено патент №118438 [11].

Визначення токсичності МФК проводилися у лабораторії фармакології та токсикології Державного науково-дослідного контрольного інституту ветеринарних препаратів та кормових добавок (Львів, Україна). 


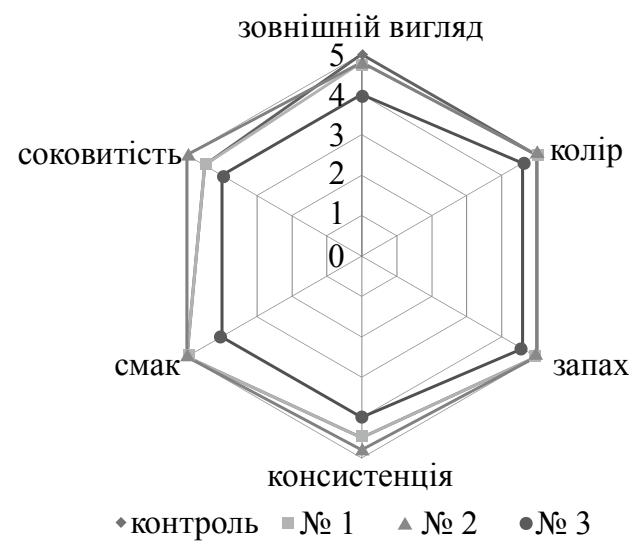

Рис. 2. Профілограми органолептичних показників МФК

Досліди проведено на білих мишах вагою 21-23 грами, які утримувалися у віварії лабораторії. Використовувалися відповідні методики за умов згодовуванням котлет з 10\% люпинового борошна та дивосилу протягом 10 днів.

Протягом дослідження у мишей, що знаходились на стандартному раціоні (контрольна група), та у тварин, що отримували готові котлети, не відмічено змін у поведінці, тварини були активні, без ознак зовнішньої агресії. Збереженість тварин була на рівні $100 \%$. При патологоанатомічному розтині макроскопічних змін в органах і тканинах не виявлено (рис. 3).

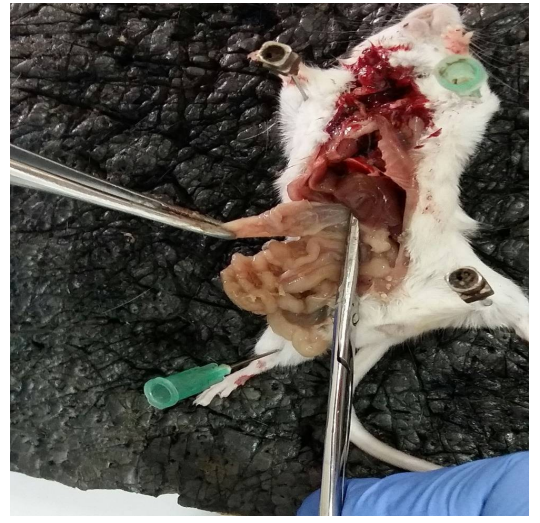

Рис. 3. Патологоанатомічний розтин піддослідної групи, що харчувалися МФК

У табл. 4 представлений аналіз внутрішніх органів контрольної та піддослідної груп.

Таблиця 4. Аналіз внутрішніх органів

\begin{tabular}{|c|c|c|c|c|c|c|c|}
\hline Група & & Печінка & Легені & Серце & Селезінка & Нирки & Маса тіла \\
\hline 1 & 2 & 3 & 4 & 5 & 6 & 7 & 8 \\
\hline \multirow{3}{*}{ Контрольна } & 1 & 0,92 & 0,50 & 0,07 & 0,09 & 0,32 & 22,2 \\
\cline { 2 - 8 } & 2 & 0,99 & 0,38 & 0,09 & 0,12 & 0,34 & 21,8 \\
\cline { 2 - 8 } & 3 & 0,92 & 0,28 & 0,11 & 0,19 & 0,36 & 19,5 \\
\hline
\end{tabular}


Продовження табл. 4

\begin{tabular}{|c|c|c|c|c|c|c|c|}
\hline 1 & 2 & 3 & 4 & 5 & 6 & 7 & 8 \\
\hline \multicolumn{2}{|c|}{$M \pm m$} & $0,94 \pm 0,02$ & $0,38 \pm 0,07$ & $0,09 \pm 0,01$ & $0,13 \pm 0,03$ & $0,34 \pm 0,01$ & $21,17 \pm 0,84$ \\
\hline \multirow{3}{*}{ Дослідна } & 4 & 1,17 & 0,24 & 0,13 & 0,19 & 0,38 & 23,0 \\
\cline { 2 - 8 } & 5 & 1,04 & 0,21 & 0,10 & 0,15 & 0,25 & 20,0 \\
\cline { 2 - 8 } & 6 & 1,38 & 0,30 & 0,13 & 0,20 & 0,31 & 21,7 \\
\hline \multicolumn{2}{|c|}{$M \pm m$} & $1,2 \pm 0,1$ & $0,25 \pm 0,03$ & $0,12 \pm 0,01$ & $0,18 \pm 0,02$ & $0,31 \pm 0,04$ & $21,57 \pm 0,87$ \\
\hline \multicolumn{2}{|c|}{$\mathrm{P}$} & $\mathrm{p}<0,05$ & $\mathrm{p}<0,05$ & $\mathrm{p}<0,05$ & $\mathrm{p}<0,05$ & $\mathrm{p}<0,05$ & $\mathrm{p}<0,05$ \\
\hline
\end{tabular}

У всіх внутрішніх органах зміни маси становлять $\mathrm{p}<0,05$, що в межах норми. Це свідчить про те, що продукція нетоксична.

Гематологічні дослідження проводили в лабораторії клініко-біологічних досліджень ДНДКІ ветеринарних препаратів і кормових добавок. Результати досліджень представлені у табл. 5-7, де № $1-3-$ проби контрольної групи, № $4-6$ - проби піддослідної групи мишей.

\section{Таблиця 5. Морфологічні показники крові мишей}

\begin{tabular}{|c|c|c|c|c|c|c|c|}
\hline $\begin{array}{c}\text { № п/п } \\
\text { проби }\end{array}$ & $\begin{array}{c}\text { Еритроцити, } \\
\text { Т/л }\end{array}$ & $\begin{array}{c}\text { Гемоглобін, } \\
\text { Г/л }\end{array}$ & $\begin{array}{c}\text { Гемато- } \\
\text { крит, } \%\end{array}$ & $\begin{array}{c}\text { МСН, } \\
\text { Пг }\end{array}$ & $\begin{array}{c}\text { МСН, } \\
\text { Г/дл }\end{array}$ & $\begin{array}{c}\text { МСV, } \\
\text { мкм }^{3}\end{array}$ & $\begin{array}{c}\text { Тромбо- } \\
\text { цити, г/л }\end{array}$ \\
\hline 1 & 8,2 & 147 & 41 & 17,8 & 35,2 & 50,7 & 669 \\
\hline 2 & 7,2 & 193 & 34 & 26,8 & 57,1 & 46,9 & 442 \\
\hline 3 & 7,8 & 126 & 37 & 16,0 & 33,8 & 47,4 & 794 \\
\hline 4 & 7,8 & 137 & 38 & 17,1 & 36,0 & 47,7 & 538 \\
\hline 5 & 9,1 & 143 & 40 & 15,6 & 35,5 & 44,1 & 971 \\
\hline 6 & 7,3 & 118 & 35 & 16,1 & 33,5 & 48,2 & 914 \\
\hline
\end{tabular}

Таблиия 6. Вміст лейкоцитів і лейкограма крові мишей

\begin{tabular}{|c|c|c|c|c|}
\hline \multirow{2}{*}{ № п/п } & \multirow{2}{*}{ Лейкоцити, г/л } & \multicolumn{3}{|c|}{ Лейкограма, $\%$} \\
\cline { 3 - 5 } & & Лімфоцити, $\%$ & Моноцити, $\%$ & Гранулоцити, $\%$ \\
\hline 1 & 8,4 & 69,8 & 10,5 & 19,7 \\
\hline 2 & 8,2 & 64,7 & 9,0 & 26,3 \\
\hline 3 & 7,8 & 71,0 & 11,0 & 18,0 \\
\hline 4 & 8,9 & 66,3 & 11,2 & 22,5 \\
\hline 5 & 5,9 & 75,7 & 6,1 & 18,2 \\
\hline 6 & 5,8 & 76,2 & 13,2 & 10,6 \\
\hline
\end{tabular}

\section{Таблиия 7. Біохімічні показники сироватки крові мишей}

\begin{tabular}{|c|c|c|c|c|c|c|c|c|}
\hline $\begin{array}{c}\text { № п/п } \\
\text { проби }\end{array}$ & $\begin{array}{c}\text { Загальний } \\
\text { білок, г/л }\end{array}$ & $\begin{array}{c}\text { Креатинін, } \\
\text { мкмоль/л }\end{array}$ & $\begin{array}{c}\text { Сечовина, } \\
\text { ммоль/л }\end{array}$ & $\begin{array}{c}\text { АсАт, } \\
\text { Од/л }\end{array}$ & $\begin{array}{c}\text { АлАт, } \\
\text { Од/л }\end{array}$ & $\begin{array}{c}\text { ЛФ, } \\
\text { Од/л }\end{array}$ & $\begin{array}{c}\text { Альфа- } \\
\text { амілаза, } \\
\text { Од/л }\end{array}$ & $\begin{array}{c}\text { Глюкоза, } \\
\text { ммоль/л }\end{array}$ \\
\hline 1 & 6,07 & 46,9 & 7,6 & 243,2 & 52,6 & 663,5 & 1652 & 5.40 \\
\hline 2 & 6,45 & 48,5 & 6,3 & 237,6 & 48,6 & 258,6 & 2113 & 5,16 \\
\hline 3 & 7,10 & 42,7 & 8,5 & 227,7 & 55,1 & 443,9 & 1821 & 4,67 \\
\hline 4 & 6,02 & 37,7 & 8,8 & 255,5 & 61,1 & 479,5 & 2075 & 4,47 \\
\hline 5 & 5,25 & 47,7 & 8,5 & 253,1 & 52,3 & 385,1 & 1781 & 5,08 \\
\hline 6 & 5.47 & 41,8 & 7,9 & 275,1 & 49,7 & 516,6 & 1943 & 6,29 \\
\hline
\end{tabular}

Результати гематологічних досліджень після 10-денного згодовування котлет у межах норми. Тож продукція немає негативного впливу на організм 
мишей. Згідно 3 методикою визначення токсичності на лабораторних тваринах котлети 3 10-відсотковим вмістом люпинового борошна та дивосилом можна вважати нетоксичними.

\section{Висновки}

Розроблено рецептури та технологічну схему виробництва м'ясних функціональних котлет. Методом дегустації за сенсорними показниками визначено найбільш якісний зразок № 2. Проведено згодовування мишам зразка № 2 - котлети з 10-відсотковим вмістом люпинового борошна та дивосилу. Визначено, що при патологоанатомічному розтині макроскопічних змін в органах і тканинах не виявлено, $\mathrm{p}<0,05$, що в межах норми. Отримано результати гематологічних досліджень крові мишей, а саме: морфологічні показники, вміст лейкоцитів і лейкограма, біохімічні показники, які підтверджують, що продукт має відповідну якість, тож його можна включати в раціон харчування людей.

\section{Література}

1. Арсеньєва Л.Ю., Бондар Н.П., Головченко О.В. Використання насіння люпину для виробництва високобілкових харчових продуктів. Вісник ДонДУЕТ. 2003. № 1(17). C. $79-83$.

2. Паска М.З., Маслійчук О.Б. Люпинове борошно - високобілковий збагачувач харчових продуктів. Продовольча індустрія АПК. 2015. № 6. С. 37-40.

3. Markovych I., Markovych I., Basarab I. Elaboration of production technology of semi-smoked sousages using lentil flour, thyme and juniper. "EUREKA: Life Science". 2016. No. 4. P. 3-8.

4. Shurduk I.. Serik M, Antonenko S., Fedak N. Effect of protein and mineral additive on consumer characteristics of meat emulsion products. Ukrainian Food Journal. 2014. No. 3(4). P. 524 534.

5. Golovko M., Serik M., Golovko T., Polupan V. Microstructural characteristics of minced meat products from use of protein-mineral additive. Ukrainian Food Journal. 2014. No. 3(2). P. 243.

6. Isolation and identification of a whey protein-sourced calcium-binding tripeptide / L. Zhao, X. Cai, Sh. Huang, Sh. Wang, Y. Huang, J. Hong, P. Rao. International Dairy Journal. 2015. No. 40. P. $16-23$.

7. Concentration oftrase elements in blood and feed of homebred animals in Souther Serbia / D. Popovich, T. Bozic, J. Stevanovic and oll. Envirimental Science and Pollution Research. 2010. No. 17. P. $1119-1128$.

8. Škrbić, B., Živančev J., Mrmoš N. Concentrations of arsenic, cadmium and lead in selected foodstuffs from Serbian market basket: Estimated intake by the population from the Serbia. Food and Chemical Toxicology. 2013. No. 58. P. 440-448.

9. Доклінічні дослідження ветеринарних лікарських засобів / І.Я. Коцюмбас, О.Г. Малик, І.П. Патерега та ін.; За ред. І.Я. Коцюмбаса. Львів: Тріада плюс. 2006. 360с.

10. Paska M., Drachuk U., Masliichuk O., Vovk V. Determination of toxicity of chopped meat-based semi-products in vivo. "EUREKA: Life Sciences". 2017. No. 5. P. 152-158. 